\title{
Surface flooding of Antarctic summer sea ice
}

\author{
S. F. Ackley ${ }^{1}$, D. K. Perovich², T. Maksym³ ${ }^{3}$ B. Weissling ${ }^{1}$ and H. Xie ${ }^{1}$
}

${ }^{1}$ NASA Center for Advanced Measurements in Extreme Environments, UTSA, San Antonio, TX, USA; ${ }^{2}$ Thayer School of Engineering, Dartmouth College, Hanover, NH, USA and ${ }^{3}$ Woods Hole Oceanographic Institution, Woods Hole, MA, USA

\section{Article}

Cite this article: Ackley SF, Perovich DK, Maksym T, Weissling B, Xie H (2020). Surface flooding of Antarctic summer sea ice. Annals of Glaciology 61(82), 117-126. https://doi.org/ 10.1017/aog.2020.22

Received: 7 October 2019

Revised: 10 April 2020

Accepted: 14 April 2020

First published online: 11 June 2020

\section{Key words:}

Ice/ocean interactions; sea ice; sea-ice growth and decay; snow/ice surface processes

\section{Author for correspondence:}

S. F. Ackley, E-mail: Stephen.ackley@utsa.edu

\begin{abstract}
The surface flooding of Antarctic sea ice in summer covers $50 \%$ or more of the sea-ice area in the major summer ice packs, the western Weddell and the Bellingshausen-Amundsen Seas. Two CRREL ice mass-balance buoys were deployed on the Amundsen Sea pack in late December 2010 from the icebreaker Oden, bridging the summer period (January-February 2011). Temperature records from thermistors embedded vertically in the snow and ice showed progressive increases in the depth of the flooded layer (up to $0.3-0.35 \mathrm{~m}$ ) on the ice cover during January and February. While the snow depth was relatively unchanged from accumulation $(<10 \mathrm{~cm})$, ice thickness decreased by up to a meter from bottom melting during this period. Contemporaneous with the high bottom melting, under-ice water temperatures up to $1^{\circ} \mathrm{C}$ above the freezing point were found. The high temperature arises from solar heating of the upper mixed layer which can occur when ice concentration in the local area falls and lower albedo ocean water is exposed to radiative heating. The higher proportion of snow ice found in the Amundsen Sea pack ice therefore results from both winter snowfall and summer ice bottom melt found here that can lead to extensive surface flooding.
\end{abstract}

\section{Introduction}

Snow ice, formed by the sea-water flooding of basal layers of the snowpack on sea ice and subsequent freezing, has been found throughout the Antarctic pack ice zone (e.g. Eicken and others, 1994; Worby and others, 1998; Jeffries and others, 2001). This process is a significant contributor to sea-ice mass balance, particularly when ocean heat retards basal growth (Jeffries and others, 2001; Maksym and others, 2012), affects ice properties (Haas and others, 2001) and is an important contributor to biological productivity for interior sea-ice communities (Fritsen and others, 1998). The highest percentage of snow ice in the regional vertical core profiles, as identified by sea ice containing an oxygen isotopic signature of snow, is as much as $40 \%$ of the core length, found in the Bellingshausen and Amundsen Seas (Jeffries and others, 2001). During winter, the formation process can be relatively continuous over large regions of the Antarctic sea-ice zone, since high ocean heat flux melts ice from the bottom, while redistribution and precipitation of snow occurs on the top. Both processes, either independently or in concert, can cause the interface between the snow and the ice to be lowered below sea level and become 'primed' for flooding (Lytle and Ackley, 2001). The flooding occurs when a warming event raises the upper ice temperature above the percolation threshold (Golden and others, 1998) and hydrostatically pushes brine and sea water into the bottom snow layer and floods it. A following cold event then freezes this snow-sea-water slurry or slush, adding a layer of snow ice by freezing on the top. The process can recycle many times through further bottom melting and/or snow accumulation and redistribution, which can then depress the snow-ice interface again, followed by another warming event causing flooding, followed by freezing. If there is a balance between bottom melting and snow-ice formation, then the measurements of ice thickness on the same floe at the beginning and end of winter may therefore show similar values. However, the material within the column of ice itself has been transformed as if on a 'vertical conveyor belt', melting from the bottom and reforming through new snow, flooding and slush freezing on the top and so, may have nearly completely different composition at the end than it did at the beginning of winter (Lytle and Ackley, 2001; Maksym and others, 2012).

In the Pacific sector of the Antarctic, however, a thick snow cover from heavy precipitation is assumed to be the major contributor to snow-ice formation (Maksym and Jeffries, 2000). Perovich and others (2004), from snow depth and temperature measurements from September to December 2001 in Marguerite Bay, Bellingshausen Sea, found that heavy snowfall $(\sim 1 \mathrm{~m} \mathrm{depth})$ increased the surface flooding layer depth. However, the layer remained unfrozen until the ice cover melted out in early December because the thick snow cover above prevented it from refreezing. In summer, the primary remaining ice-covered areas are in the western Weddell Sea and the Amundsen Sea, but both the temporal evolution of flooding and ocean heat flux contributions to ice melt are very limited for this region. From ISPOL (Ice Station Polarstern) measurements in the Weddell Sea, McPhee (2008) found early summer (December) ocean heat fluxes (from the ocean to the ice) averaged $\sim 15 \mathrm{~W} \mathrm{~m}^{-2}$. By late February (end of summer), measurements in the Weddell Sea (Lytle and Ackley, 1996) found heat fluxes of only $7-8 \mathrm{~W} \mathrm{~m}^{-2}$. Since no measurements are available for January, if these values are partitioned over the summer period, they would suggest up to $\sim 20 \mathrm{~cm}$ decrease in ice thickness and consequently perhaps only an additional $7 \mathrm{~cm}$ of flooding 


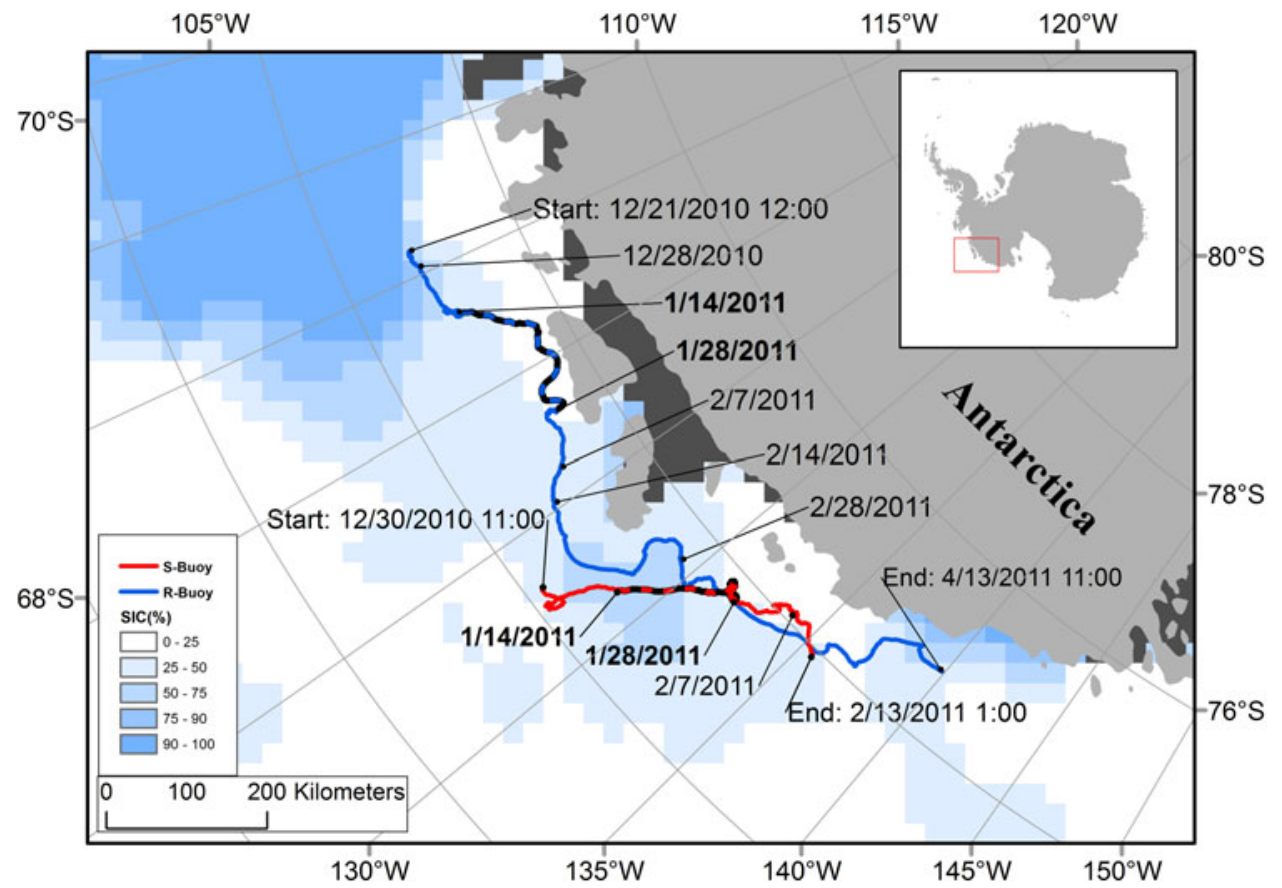

Fig. 1. Drift tracks on the Amundsen sea pack ice of the R-Buoy (blue) deployed 21 Dec 2010 at $72.8 \mathrm{~S}, 113.9 \mathrm{~W}$ and S-Buoy (red) deployed 30 Dec 2010 at $72.1 \mathrm{~S}$, 127.0W. Ice concentrations, prepared from passive microwave satellite data (Cavalieri and others, 1996), for 11 Jan 2011 are also shown.

Table 1. Deployment positions, start and end dates, and sensors for the R-Buoy and S-Buoy

\begin{tabular}{|c|c|c|}
\hline DATA TYPE & R-Buoy & S-Buoy \\
\hline Start date & 21 Dec 2010 & 31 Dec 2010 \\
\hline Initial position & $72.8 \mathrm{~S}, 114.22 \mathrm{~W}$ & $72.12 \mathrm{~S}, 127.06 \mathrm{~W}$ \\
\hline End date & 13 April 2011 & 13 Feb 2011 \\
\hline Position sensor & Garmin GPS16-HVS (at surface) & Garmin GPS16-HVS (at surface) \\
\hline Atmospheric pressure & $\begin{array}{l}\text { Campbell SR50A-L24 sensor ( } 2.35 \mathrm{~m} \text { above the snow surface) } \\
( \pm 2 \mathrm{mb})\end{array}$ & $\begin{array}{l}\text { Campbell SR50A-L24 sensor ( } 2.35 \mathrm{~m} \text { above the snow surface) } \\
( \pm 2 \mathrm{mb})\end{array}$ \\
\hline $\begin{array}{l}\text { Air temperature/incoming radiation } \\
\text { (PAR) sensor }\end{array}$ & $\begin{array}{l}\text { Campbell SR50A-L24 sensor ( } 2.35 \mathrm{~m} \text { above the snow surface) } \\
\left( \pm 0.1^{\circ} \mathrm{C}\right)\end{array}$ & $\begin{array}{l}\text { Campbell SR50A-L24 sensor ( } 2.35 \mathrm{~m} \text { above the snow surface) } \\
\left(+/ 0.1^{\circ} \mathrm{C}\right)\end{array}$ \\
\hline $\begin{array}{l}\text { Temperature profile } \\
\text { (air-snow-ice-water) }\end{array}$ & $\begin{array}{l}\text { YSI- } 44033-\mathrm{BP} \text { thermistors (at } 0.1 \mathrm{~m} \text { spacing from } 0.5 \mathrm{~m} \text { above } \\
\text { snow to } 0.7 \mathrm{~m} \text { below ice) }\left( \pm 0.01^{\circ} \mathrm{C}\right)\end{array}$ & $\begin{array}{l}\text { YSI- } 44033 \text {-BP thermistors (at } 0.1 \mathrm{~m} \text { spacing from } 0.5 \mathrm{~m} \text { above } \\
\text { snow to } 0.7 \mathrm{~m} \text { below ice })\left( \pm 0.01^{\circ} \mathrm{C}\right)\end{array}$ \\
\hline Initial snow depth & $0.404 \mathrm{~m}$ & $0.61 \mathrm{~m}$ \\
\hline Snow depth sensor & $\begin{array}{l}\text { Campbell SR50A-L24 acoustic sensor ( } 2.35 \mathrm{~m} \text { above the snow } \\
\text { surface) }( \pm 0.02 \mathrm{~m})\end{array}$ & $\begin{array}{l}\text { Campbell SR50A-L24 acoustic sensor }(2.35 \mathrm{~m} \text { above the snow } \\
\text { surface) } \\
( \pm 0.02 \mathrm{~m})\end{array}$ \\
\hline Incoming sub-ice irradiance sensor & Satlantic 7 channel underwater radiometer & None \\
\hline Water CTD sensor & None & $\begin{array}{l}\text { Sea-Bird MicroCAT SBE } 37 \text {-SI with pressure sensor }\left( \pm 0.001^{\circ} \mathrm{C} \text {; }\right. \\
\pm 0.0005 \mathrm{psu})\end{array}$ \\
\hline
\end{tabular}

over the summer (Adolphs, 1998) from bottom melting. As snow precipitation was presumed light during the summer months (as verified here), little additional flooding from snow loading was expected.

Processes during the midsummer month of January may provide an important missing component of precipitation influences and the ocean heat flux effect on bottom melting-induced flooding in Antarctic pack ice zones. To address this issue, Ice Mass Balance (IMB) buoy measurements are reported here for summer values (January-February) for the Amundsen Sea pack ice for precipitation, ocean heat flux and surface flooding.

\section{Instruments and methods}

\section{Instruments}

Figure 1 shows the deployment locations and subsequent drift of the two CRREL IMB buoys (also called IMBs here, or individually as the 'Radiometer' or R-Buoy and the 'SeaBird' or S-Buoy) in the
Amundsen Sea during the OSO 10-11 (Oden Southern Ocean 2010-11) program. The buoys were deployed from the icebreaker ODEN in its transit from South America to McMurdo Station (10 December 2010 to 10 January 2011). Table 1 shows the sensors and periods of operation for each buoy.

As well as the common sensors listed in Table 1, the R-Buoy measured irradiance at the ice undersurface (Satlantic 7 channel underwater radiometer on an $\mathrm{L}$-arm looking upward from $\sim 0.85$ $\mathrm{m}$ depth) and incoming radiation (PAR, Photosynthetically Active Radiation) above the upper snow surface, while the S-Buoy was equipped to measure conductivity, temperature and depth below the ice (Sea-Bird MicroCAT SBE 37-SI with pressure sensor) mounted on an underwater mast $\sim 0.85 \mathrm{~m}$ below the ice bottom. IMB sensors were autonomously sampled at intervals varying from 2 to $6 \mathrm{~h}$, depending on the sensor. Data were saved in a data logger (Campbell CR1000-ST-SW-NC), and transmitted through the Iridium system and are available online at https://www.usapdc.org/view/dataset/600106 (Ackley, 2013) The IMB life spans were from 30 December 2010 to 13 February 2011 ( $\sim 45$ d) for the 
S-Buoy and from 20 December 2010 to 13 April 2011 for the R-Buoy ( $103 \mathrm{~d})$.

In the Antarctic sea-ice zone, there has been little observed surface ablation in summer, so an interesting characteristic feature is the evolution of ice thickness as bottom melt dominates and whether substantial loss of ice thickness can happen at the ice bottom surface alone. Ice bottom melt is driven by the ocean heat flux.

\section{Methods}

Two methods, bulk parameterization and the residual method (Shirasawa and Lepparanta, 2009), were employed here to determine the magnitude and variation of the ocean heat flux. Time series temperature records from the snowpack were used to determine the progression of the surface flooding layer depth.

\section{Parameterization of bulk ocean heat flux from ocean measurements}

Water temperature elevation above its freezing point has been identified as the measure of the available heat content in the mixed layer beneath the ice (e.g. Josberger, 1987; Morison and others, 1987; Omstedt and Wettlaufer, 1992; McPhee and others, 1996; Sirevaag, and others, 2010). Morison and others (1987) parameterized the ocean heat flux, $Q$, using the product of the deviation of the sea-water temperature above the freezing point $\left(T-T_{\mathrm{f}}\right)$, the friction velocity $\left(u^{\star}\right)$ and the bulk Stanton number $C_{\mathrm{H}}$ times the density $\rho_{\mathrm{w}}$ and specific heat of sea water $c_{\mathrm{w}}$. After Morison and others (1987) and McPhee and others (1999), Q, the ocean heat flux, is:

$$
Q=\rho_{\mathrm{w}} c_{\mathrm{w}} u^{*} C_{\mathrm{H}}\left(T-T_{\mathrm{f}}\right)
$$

where $\rho_{\mathrm{w}}$ is the sea-water density $\left(1024 \mathrm{~kg} \mathrm{~m}^{-3}\right), c_{\mathrm{w}}$ is the heat capacity $\left(3980 \mathrm{~J}\left(\mathrm{~kg}^{\circ} \mathrm{C}\right)^{-1}\right), u^{*}$ is the friction velocity and $C_{\mathrm{H}}$ is the turbulent Stanton number. Ice speed can be considered to scale with the turbulent mixing $\left(u^{\star}\right)$, because, while surface ocean currents are unknown, they are mostly slow relative to the ice drift (McPhee and others, 1999). Josberger (1987) showed the bulk heat transfer coefficient varied modestly over a wide range of ice melting conditions; however, McPhee and others (1999) suggested it may actually be fairly uniform, and a constant $C_{\mathrm{H}}=0.0056$ should be used for the Weddell Sea. In the absence of a measurement of the friction velocity, the relative ice speed, scaled by the square root of the drag coefficient, has been substituted for $u^{*}$ for various experiments and modeling for melting sea ice in the Arctic (e.g. Josberger, 1987; Morison and others, 1987; Omstedt and Wettlaufer, 1992). Morison (1995) used the product of a buoy's drift speed and temperature elevation as proportional to the ocean heat flux. Based on drag and heat transfer coefficients measured during the AnzFlux drift stations (McPhee, 1995) at the same time as his buoy data, Morison (1995) derived the constant of proportionality between the product $U_{\mathrm{i}}\left(T-T_{\mathrm{f}}\right)$ and ocean heat flux as $700 \mathrm{~W} \mathrm{~m}^{-2}\left({ }^{\circ} \mathrm{C}\right)^{-1}\left(\mathrm{~m} \mathrm{~s}^{-1}\right)^{-1}$. With buoy drift speed and temperature elevation measurements only available here also, but with the absence of direct measurements of heat and drag coefficients, we have adopted his relationship to compute ocean heat flux. The ice speed, $U_{\mathrm{i}}, T\left({ }^{\circ} \mathrm{C}\right), T_{\mathrm{f}}\left({ }^{\circ} \mathrm{C}\right)$ and $700 \mathrm{~W} \mathrm{~m}^{-2}$ $\left({ }^{\circ} \mathrm{C}\right)^{-1}\left(\mathrm{~m} \mathrm{~s}^{-1}\right)^{-1}$ are used in Eqn (1), to determine the ocean heat flux, $Q\left(\mathrm{~W} \mathrm{~m}^{-2}\right)$ :

$$
Q=700 U_{\mathrm{i}}\left(T-T_{\mathrm{f}}\right) .
$$

After Fujino and others (1974), the freezing point temperature, $T_{\mathrm{f}}$, is

$$
\begin{aligned}
T_{\mathrm{f}}= & -0.057 S+1.710523 E^{-3} S^{\frac{3}{2}}-2.154996 E^{-4} S^{2} \\
& -7.53 E^{-4} P,
\end{aligned}
$$

where $S$ is the surface water salinity in psu and $p$ is the pressure in decibars.

Surface salinity is computed from SeaBird CTD measurements of conductivity, temperature and pressure at $\sim 2 \mathrm{~m}$ depth $(\sim 1 \mathrm{~m}$ below the ice). The sea-water equation of state (Fofonoff, 1985) computes the salinity used in Eqn (3) from conductivity, temperature and pressure from the SeaBird sensor for that buoy. The freezing point is then used in Eqn (2) with the measured water temperature to determine $Q$, the ocean heat flux. For the R-Buoy, since no salinity measurements were taken, an approximation to its freezing point temperature was calculated using the average salinity ( $33.3 \mathrm{psu}$ ) measured by the Seabird sensor on the other buoy. Together with the R-Buoy's water temperatures, this approximate freezing point temperature was used to calculate $Q$. The possible error in the ocean heat flux, $Q$, for the R-Buoy that used this approximation to the freezing point temperature is described in the 'Results' section.

\section{Residual method from ice freezing or melting for computing ocean heat flux}

When air temperatures are sufficiently cold and the ice-water interface is not in thermal balance, heat may be conducted through the ice and snow and lost to the atmosphere, thereby establishing the potential for ice growth (Weeks and Ackley, 1986; Lytle and Ackley, 1996). During such conditions and from the steady-state heat balance, ocean heat flux (Maykut, 1986) can be written as the residual balance at the ice bottom between the upward conductive heat flux through the ice and the latent heat flux due to ice growth at the bottom (neglecting the small amounts of sensible and latent heat changes within the ice).

During this study, however, the ice was isothermal at the freezing point since surface air temperatures were usually warm during January and February, so the temperature gradients near the ice bottom approached zero then and the conductive heat flux was therefore also near zero. The snow cover was consistently deep enough $(>0.2 \mathrm{~m})$ to further insulate the bottom layers from the cold air temperatures when they occasionally occurred, therefore preventing heat conduction between ocean and atmosphere through the ice. Ice at the bottom was instead melting continuously, under the influence of the ocean heat flux alone. As such, the ocean heat flux $Q$, without a conductive term, is:

$$
Q=\frac{\rho_{\mathrm{i}} L \mathrm{~d} H}{\mathrm{~d} t},
$$

$\rho_{\mathrm{i}}$ is the density of the sea ice (assumed $920 \mathrm{~kg} \mathrm{~m}^{-3}$; Weeks and Ackley, 1986), $L$ is the latent heat of fusion and $\mathrm{d} H / \mathrm{d} t$ is the measured rate of ice thickness change in $\mathrm{m} \mathrm{s}^{-1} . L$ is given by Ono (1968) as

$$
L=333394-2113 T_{\mathrm{i}}-114.2 S_{\mathrm{i}}+18040 \frac{S_{\mathrm{i}}}{T_{\mathrm{i}}}
$$

The average ocean heat flux melts the ice at melt rate $\mathrm{d} H / \mathrm{d} t$ $\left(\mathrm{m} \mathrm{s}^{-1}\right)$. The melt rate is determined from the slope of the plots of ice thickness (net loss) with time. From these computations, converting ice melt rate from $\mathrm{ms}^{-1}$ to the more conveniently 
Fig. 2. Sensor records from the S-Buoy (from top to bottom) with time (4 Jan to $3 \mathrm{Feb}$ ) are: (a) barometric pressure (top), (b) air temperature (2nd from top) measured at $2.35 \mathrm{~m}$ above the surface, (c) ice temperatures (3rd from top, colored panel) and (d) water temperature (bottom panel, taken at $\sim 0.85 \mathrm{~m}$ below the initial ice bottom). Zero line in (c) is at the snowice interface at installation.

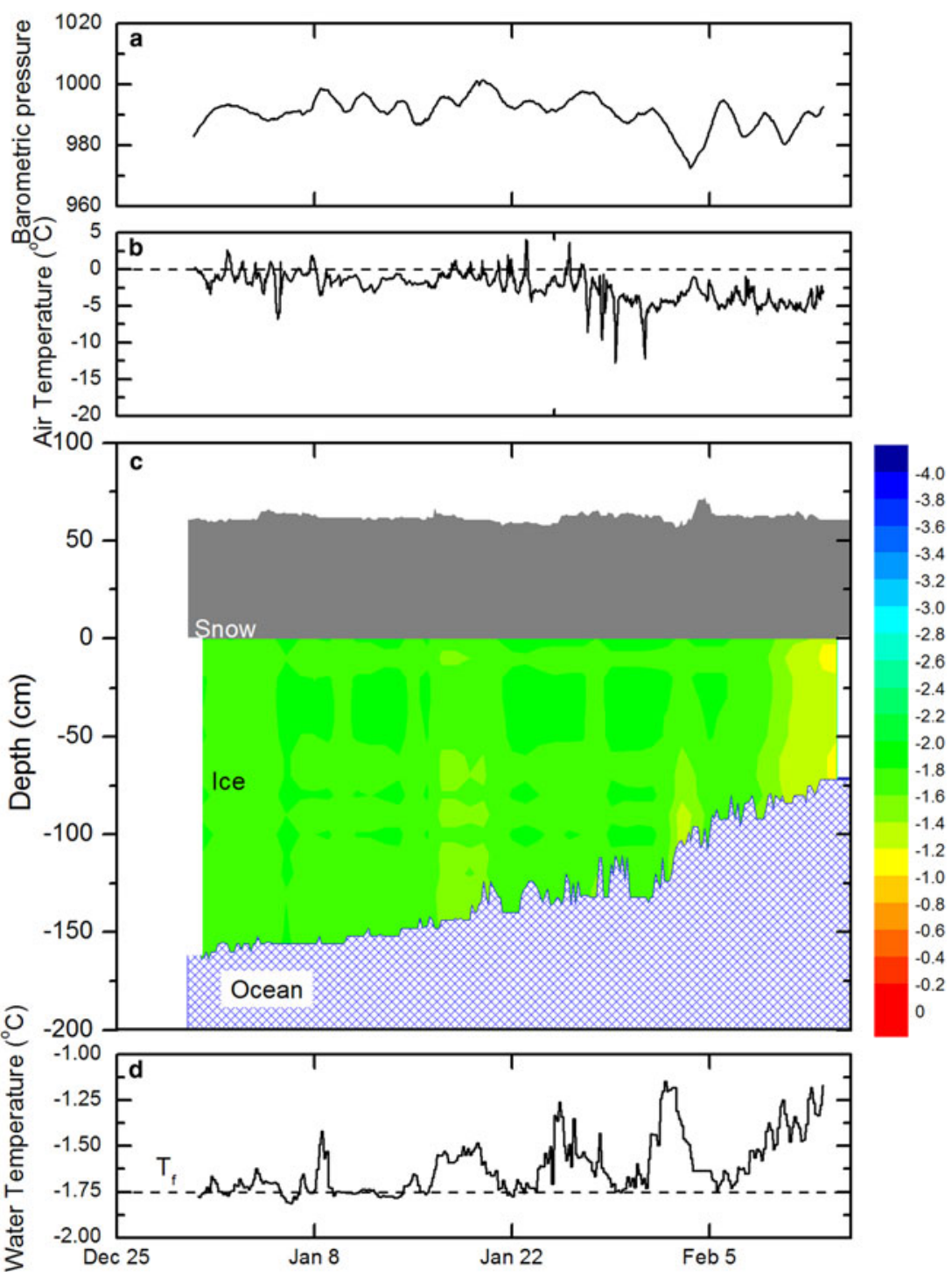

observed $\mathrm{m} \mathrm{d}^{-1}$, for example, gives an equivalent ocean heat flux of $28 \mathrm{~W} \mathrm{~m}^{-2}$ for a melt rate of $0.01 \mathrm{~m} \mathrm{~d}^{-1}\left(1 \mathrm{~cm} \mathrm{~d}^{-1}\right)$.

\section{Determination method for surface flooding changes}

Because the surface flooding takes place at the interface between the snow and sea ice, the presence or absence of surface flooding can be determined using the sensors there, i.e. from thermistor (temperature) records. These temperature records, if flooded, will reflect a temperature near the freezing point of sea water $\left(\sim-1.7^{\circ} \mathrm{C}\right)$. However, since the flooded layer is an ice-water bath, the freezing point can also be affected by the salinity of the layer, that is, the salinity can be reduced by adding fresh water from snow or ice melt if temperatures or radiation can cause melting. Since air temperatures are near zero, temperatures in the unflooded snow cover can also be found of this value. An assessment of whether a layer is flooded from the temperature records therefore requires a set of logical criteria and evaluation of temperature variation with time. In conditions changing between warm and cold, a particular location is determined to be in 'snow' (without flooding) if it shows temperatures that can take on values both above and below the freezing point $\left(-1.7^{\circ} \mathrm{C}\right)$ of sea water (with a diurnal cycle also), while flooded snow will be near constant at or near $-1.7^{\circ} \mathrm{C}$, and without a diurnal cycle.

\section{Data from the buoys}

Figure 1 shows the drift tracks of the R-Buoy (blue track) and S-Buoy (red track) starting from their deployment times $10 \mathrm{~d}$ apart in late December 2010. On 12 February 2011, the S-Buoy stopped transmitting after melting out as it entered the ice edge zone at that time in the south-central Amundsen Sea. The R-Buoy continued transmitting into the freeze-up period until 13 April 2011, when it then stopped, presumably caused by being overridden by ice in an ice deformation event (since it was in freezing conditions in early April and therefore unlikely to be melted out as the S-Buoy was in February).

In Figure 2, the data for the S-Buoy time series for air pressure, air temperature at $2 \mathrm{~m}$ height, ice temperatures and water temperature are shown. Only ice temperatures are shown in Figure $2 \mathrm{c}$ (temperatures from thermistors above and in the snow and below the ice bottom are masked out). The air temperature (Fig. 2b) is derived from the thermistor in the ventilated, radiation shielded can at $2.35 \mathrm{~m}$ above the snow surface, and the water temperature in Figure $2 \mathrm{~d}$ is taken from the SeaBird CTD suspended $\sim 0.85 \mathrm{~m}$ below the ice bottom. The top surface of the snow was derived from the downward-looking sonar sensor, which measured distance from a height of $\sim 2.35 \mathrm{~m}$ above the snow surface from a mast frozen into the ice. From the air temperature record (Fig. 2b) in the early part of January, only a few small excursions of air temperature above $0^{\circ} \mathrm{C}$ were seen. 


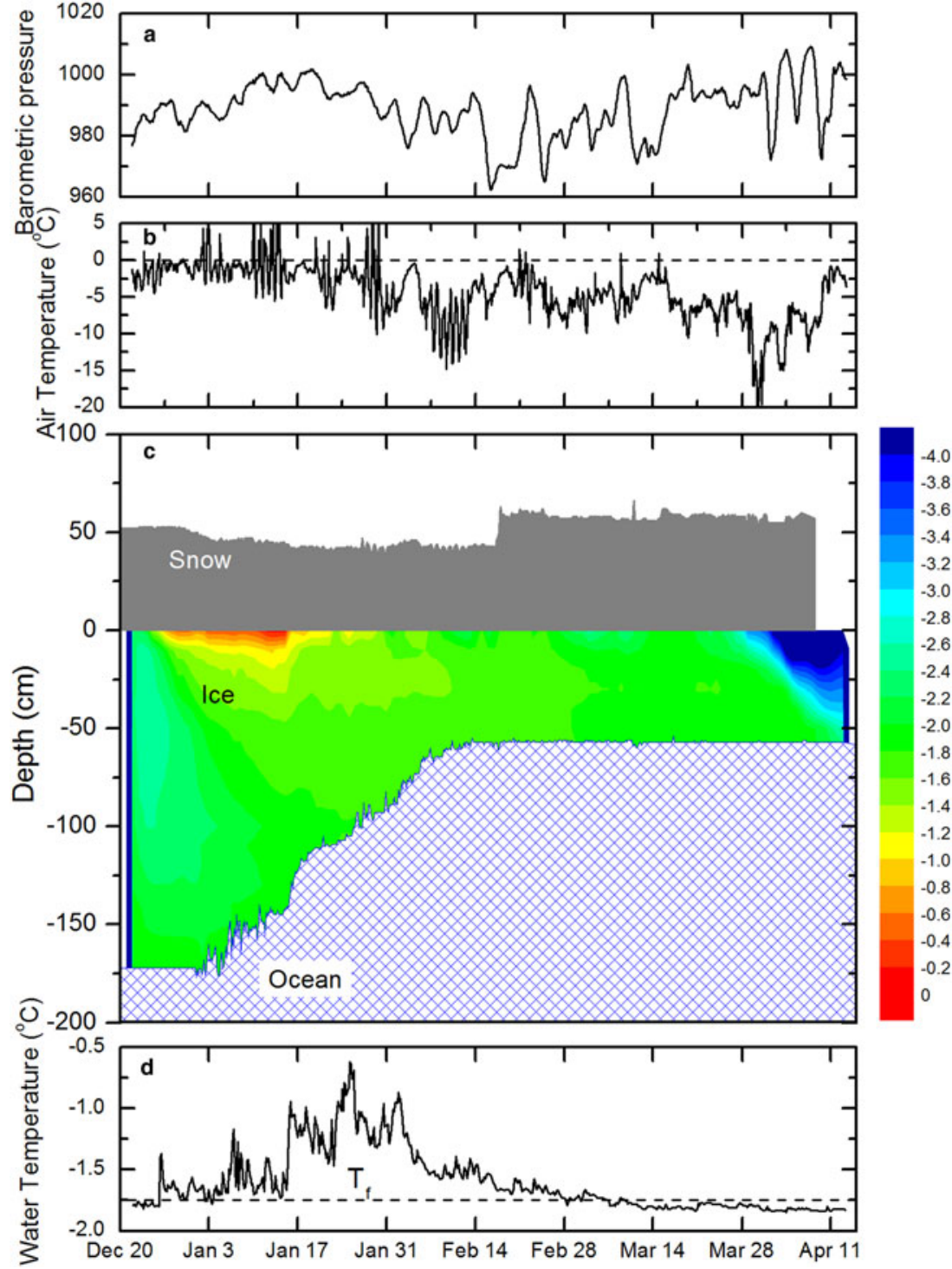

Fig. 3. Sensor records from the R-Buoy (from top to bottom) with time (23 Dec 2010 to 11 April 2011) are: (a) barometric pressure (top), (b) air temperature (2nd from top) measured at 2.35 $\mathrm{m}$ above the surface, (c) ice temperatures (3rd from top, colored panel) and (d) water temperature (bottom panel, taken at $\sim 1.5$ $\mathrm{m}$ below the initial ice bottom). Zero line in (c) is at the snowice interface at installation.
Ice temperatures below the bottom of the snow layer (at $0.4 \mathrm{~m}$ depth) were generally isothermal at $\sim-1.7^{\circ} \mathrm{C}$, i.e. near the freezing point of sea water of $\sim 33$ psu as derived from the conductivity in the CTD measurements. This sensor indicated a small fluctuating change in snow depth $(<2 \mathrm{~cm})$, so no net accumulation or ablation is discernible during the record length. The bottom surface of the ice, shown as the variable boundary between the ice temperature record and the water below, was derived from the upward-looking sonar record of the transducer fixed below the ice. The bottom surface of the ice generally rose through melting throughout January and then into early February up until the buoy demise on 12 February. From the ice thickness data, the rate of ice bottom melting rapidly accelerated from 3 February until data transmission ceased on 12 February.

In Figure 3, similar time series records for the R-Buoy are shown, air pressure, air temperature at $2 \mathrm{~m}$ height, ice temperatures from thermistors and water temperature. Only ice temperatures are shown in Figure $3 c$, with temperatures from thermistors above and in the snow and below the ice bottom masked out. As a CTD was not installed on this buoy, the water temperature is taken from the thermistor on the bottom of the rod, in this case $\sim 1.5 \mathrm{~m}$ below the initial ice bottom. The ice temperatures in Figure $3 \mathrm{c}$ and water temperature record in Figure 3d show that the buoy captured the warm temperatures for the full summer melting period for the ice floe as ice temperatures transitioned from cold $\left(-2.5^{\circ} \mathrm{C}\right)$ initially in late December to isothermal $\left(-1.8^{\circ} \mathrm{C}\right)$ by 12 January, and back to cold, at the top of the ice around 10-15 March and dropping to $<-3.0^{\circ} \mathrm{C}$ throughout the ice by the end of the buoy record (around 13 April). Similarly, the water temperature (Fig. 3d) was near the freezing point for $\sim 2 \mathrm{~d}$ initially (23 December-25 December) and started to show substantial warming events, some to above $-1.0^{\circ} \mathrm{C}$, corresponding with ice bottom melt (Fig. 3c), until cooling in the middle of February. Snow elevation increased by $\sim 10 \mathrm{~cm}$ on 16-17 February. Since this change corresponded with the lowest barometric pressure (Fig. 3a), low-pressure storm activity could have either precipitated snow or high storm winds could have drifted snow under the sensor. This change was the only snow event in the 4-month buoy record of any significant magnitude.

\section{Freezing point temperature}

In order to calculate the ocean heat flux (Eqn (2)), the data needed are the freezing point temperature (from Eqn (3)), and water temperatures (Figs $2 \mathrm{~d}$ and $3 \mathrm{~d}$ ) to compute temperature elevation above freezing, and the drift speed (Morison, 1995; McPhee and others, 1999).

\section{Water temperature elevation above freezing}

For the freezing point temperature, we first used the SeaBird (CTD) conductivity measurements to compute salinities using the routine www.mbari.org/staff/etp3/matlab/salinity.m (S. Stammerjohn, pers. 


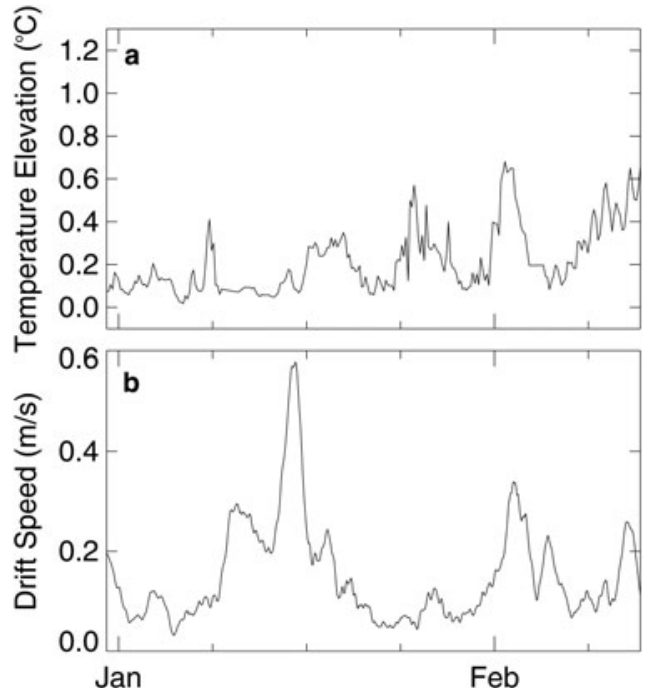

Fig. 4. (a)Temperature elevation of the S-Buoy's water temperature above its in situ freezing point. The water temperature was measured from the SeaBird CTD mounted $\sim 0.85 \mathrm{~m}$ below the ice and the freezing point temperature was calculated from the sea-water conductivity (salinity), temperature and pressure measured on the same unit. (b) S-Buoy drift speed with time, computed from differencing GPS positions taken at nominally hourly intervals, then smoothing with a $24 \mathrm{~h}$ running mean.

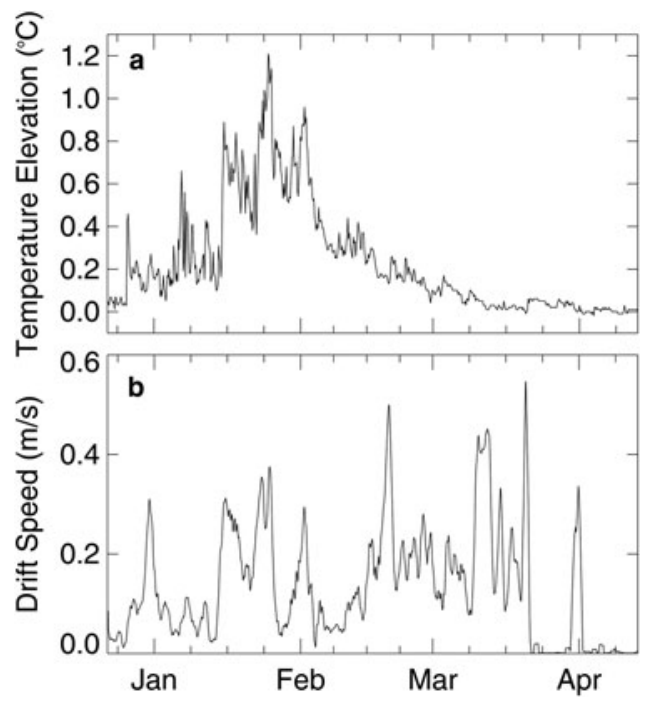

Fig. 5. (a) R-Buoy temperature elevation of the water temperature above its in situ freezing point. The water temperature was measured from the radiometer thermistor mounted $\sim 1.5 \mathrm{~m}$ below the ice and the freezing point temperature was the calculated freezing point temperature using the R-Buoy temperature and the S-Buoy CTD measurements of average salinity (see text). (b) R-Buoy drift speed with time, computed from differencing GPS positions taken at nominally hourly intervals, then smoothing with a $24 \mathrm{~h}$ running mean.

comm., equations based on Fofonoff, 1985). Salinities were computed at four-hourly intervals (with some data gaps) for the period of operation of the buoy from 31 December 2010 until 13 February 2011. Salinity variations were quite small with all values found between $32.771 \mathrm{psu}$ and $33.817( \pm 0.0005)$ psu, a total range of only $\sim 1$ psu. The average salinity was $33.3 \pm 0.3$ psu. Using Eqn (3), the freezing point temperature was then computed. Figure $4 \mathrm{a}$ shows the difference between the S-Buoy water temperature and the freezing point, expressed as the temperature elevation above the freezing point where both the salinity to compute the freezing point (Fujino and others, 1974; Fofonoff, 1985) and the water temperature were measured by the CTD. Figure 5a shows the difference between the R-Buoy water temperature and an average freezing point temperature. Since the R-Buoy did not have conductivity (salinity) measurements, we estimated the freezing point temperature for it using the average salinity measured by the S-Buoy ( 33.3 psu). The small range of salinity variability assumed for the R-Buoy track to estimate the freezing point is reasonable as both buoys tracked closely and we assume they encountered similar on-shelf water masses. The error induced in the ocean heat flux by this assumption was computed and is discussed later.

\section{Drift speed}

Drift speeds of the buoys were determined by differencing positions obtained by the onboard GPS on each buoy and using the Haversine formula to obtain distances on the curved Earth surface and then dividing by the time interval (usually hourly) between positions. A running mean $(24 \mathrm{~h})$ was then applied to this record to smooth out some of the speed errors that are otherwise magnified by small errors in positioning. The resulting smoothed drift speeds for the two buoys are shown in Figures $4 \mathrm{~b}$ (S-Buoy) and 5b (R-Buoy).

\section{Results}

\section{Changes in surface flooding depths}

Figure 6 shows four thermistor time series (S-Buoy) initially in snow, distances shown are referenced to near the initial bottom boundary between flooded and dry snow: The thermistor at $0 \mathrm{~cm}$ (T11) is near the snow-ice interface at the time of placement; above it in the snow at $10 \mathrm{~cm}$ intervals are: $+10 \mathrm{~cm}$ (T10), $+20 \mathrm{~cm}$ (T9) and $+30 \mathrm{~cm}$ (T8). Nearest the top of the snow, at $+30 \mathrm{~cm}$ (T8) in Figure 6 illustrates the response of a sensor that remained in snow for nearly the entire record. The record for $+30 \mathrm{~cm}$ (T8) initially shows strong temperature cycling with some solar heating response as its temperature cycles above and below $0^{\circ} \mathrm{C}$, as $0^{\circ} \mathrm{C}$ is the upper limit of temperature in the snow at the snow melting point if shielded from the sun, until 14 January. Generally, its temperature continues to cycle but only up to $-1^{\circ} \mathrm{C}$ until late in the record (28 January-3 February) when this snow temperature, in response to continuing cold air temperatures, cycles below $-2^{\circ} \mathrm{C}$, while still maintaining a diurnal cycle. The bottom curve, at $0 \mathrm{~cm}$ (T11) however, became flooded around 6 January as its temperature dropped to $\sim-1.7^{\circ} \mathrm{C}$ and stayed there throughout the record. Little variability is seen there, as the flooded layer provides a latent heat sink as an ice-water bath at a constant temperature, so only phase change, and not temperature change, occurs as heat is conducted into it from above, and therefore, the air diurnal temperature cycles seen in the snow above are not seen here. Similarly, the thermistors between show flooding at $+10 \mathrm{~cm}$ (T10) on 16 January and $+20 \mathrm{~cm}$ (T9) on 28 January, and finally, $+30 \mathrm{~cm}$ (T8) on 4 February, when it appears over half the full depth $(0.60 \mathrm{~m})$ of the snowpack was flooded. A similar analysis of the R-Buoy thermistor records (not shown) indicates flooding of similar magnitude $(\sim 20-30 \mathrm{~cm})$ during the same period in its thinner snowpack of 0.4 $\mathrm{m}$ total depth. With the relatively coarse spacing $(10 \mathrm{~cm})$ for the thermistors, there is however uncertainty in the precise level of surface flooding within that $10 \mathrm{~cm}$ level from these records.

The level of flooding can also be determined through consideration of isostatic balance. The isostatic balance equation, where mass of water displaced equals the combined mass of ice, snow and slush, is:

$$
\rho_{\mathrm{w}} t+\rho_{\mathrm{w}} d=\rho_{\mathrm{s}} s+\rho_{\mathrm{sl}} d+\rho_{\mathrm{i}} t
$$

where $\rho_{\mathrm{w}}, \rho_{\mathrm{s}}, \rho_{\mathrm{s}}, \rho_{\mathrm{i}}$ are the densities of sea water, snow, slush and ice, respectively, and tis the ice thickness, $d$ is the slush depth and $s$ is the snow depth. We use $1030 \mathrm{~kg} \mathrm{~m}^{-3}$ for sea-water density, $940 \mathrm{~kg} \mathrm{~m}^{-3}$ for ice density (Weeks and Ackley, 1986), $300 \mathrm{~kg} \mathrm{~m}^{-3}$ for snow density 


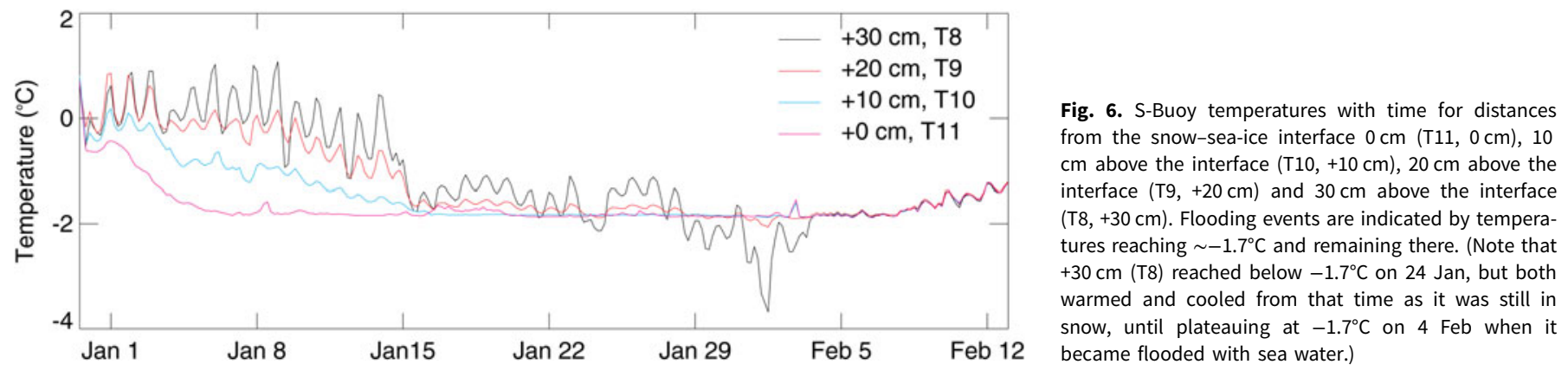

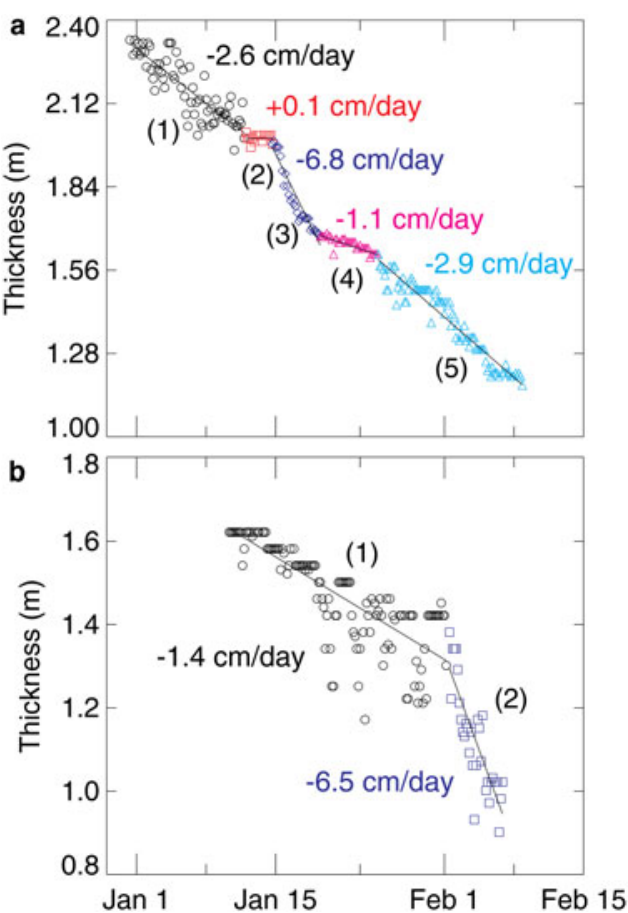

Fig. 7. (a) R-Buoy ice thickness with time (1 Jan-10 Feb). Linear regression lines with slopes indicative of ice melting rates in $\mathrm{cm} \mathrm{d}^{-1}$ are shown for five segments of the data. Ice thickness changes at four-hourly intervals were determined from an upward-looking sonar mounted $\sim 0.85 \mathrm{~m}$ below the initial ice bottom. (b) S-Buoy ice thickness with time (10 Jan-7 Feb). Linear regression lines with slopes indicative of ice melting rates in $\mathrm{cm} \mathrm{d}^{-1}$ are shown for two segments of the data. Ice thickness changes at four-hourly intervals were determined from an upward-looking sonar mounted $\sim 0.85 \mathrm{~m}$ below the initial ice bottom.

(Lewis and others, 2011) and $940 \mathrm{~kg} \mathrm{~m}^{-3}$ for slush density (Lewis and others, 2011). During the flooding process, we assume that snow compaction takes place such that the flooding snow is at least $50 \%$ ice by volume (Jeffries and others, 2001), so we set the slush density the same as the warm ice density. This slush density of $940 \mathrm{~kg} \mathrm{~m}^{-3}$ was also computed when initial field measured values of snow depth, slush depth and ice thickness were used and Eqn (6) solved for the slush density instead of the slush depth. Solving Eqn (6) for the slush depth in mid-February after $1 \mathrm{~m}$ of ice loss on the R-Buoy gives a slush depth of $0.35 \mathrm{~m}$ or an increase of slush depth of $0.27 \mathrm{~m}$, a value for flooded depth increase in agreement with that determined from the thermistor string records, of between 0.20 and $0.30 \mathrm{~m}$, within their resolution.

\section{Ice thickness changes from bottom melting}

Figure 7a (R-Buoy) shows the ice thickness changes computed from the upward looking sonar data (every $4 \mathrm{~h}$ ) plotted versus days in January and February. As shown in Figure 3c, the ice thickness stopped decreasing and leveled off to a constant value after 9 February. Total ice thickness change between the start of record (30 December) and end of the melting (around 9 February) was $\sim 1.1 \mathrm{~m}$. As shown in Figure $7 \mathrm{a}$, the ice loss change was divided into five separate periods (by eye) and the data were linearly regressed for each of those periods. The slope of the line is given in $\mathrm{m} \mathrm{d}^{-1}$ (Table 2) and varied from a high of $0.068 \mathrm{~m} \mathrm{~d}^{-1}$ in mid-January (Period 3) to a low of $0.011 \mathrm{~m}$ $\mathrm{d}^{-1}$ later in January (Period 4). Period 2 (early January) showed no change within the accuracy of the sonar (estimated at 0.02 $\mathrm{m}$, Ackley and others, 2015) but is the shortest record (1-2 d), so is not considered. In Figure $7 \mathrm{~b}$, the ice thickness changes are shown for the S-Buoy over the same time period. (Days are included here from 3 February to 7 February, not shown in Fig. 2c.) For the S-Buoy, due to the presence of considerable data variability probably caused by a larger rms bottom roughness, only two periods were separable. The variability in sonar return for the ice bottom was probably due to a rougher bottom that melted differentially at the S-Buoy site, compared to a more level, more evenly melting undersurface at the R-Buoy. At the rougher bottom surface, the first sonar return would depend on the distance from the first normal surface to the incoming wave, which may not be the closest point to the sonar. If the angle changed slightly as the block surface melted, then the return may come from a different point that was then flatter and that surface may be $20 \mathrm{~cm}$ or more closer to or further away than the initial point. As the angle can change back, the initial surface may again be the reflecting surface so the ice thickness measurements may show high variability that is inconsistent with large changes in actual ice thickness over short periods of time. Over a several week long period however, the trend of the ice thickness changes (Fig. 7b) can effectively show the longer term change due to bottom melting.

From 10 January to 1 February, ice melt was generally much lower $\left(0.014 \mathrm{~m} \mathrm{~d}^{-1}\right)$ than the corresponding period for the R-Buoy (Table 2). As the S-Buoy approached the ice edge in early February, the melt rate increased to $0.065 \mathrm{~m} \mathrm{~d}^{-1}$, so the overall average melt rates for the two buoys over the entire period of overlap became much closer (last column in Table 2.).

\section{Ocean heat flux from ocean property measurements}

Ocean heat fluxes calculated for the S-Buoy and R-Buoy are shown in Figure 8, found with Eqn (2) using the temperature elevation above the freezing point (Figs $4 \mathrm{a}$ and $5 \mathrm{a}$ ) and the drift speed (Figs $4 \mathrm{~b}$ and $5 \mathrm{~b}$ ) at each co-measured point. The drift speed is used rather than a (scaled) $u^{*}$ in Eqn (2), although strictly speaking, the relative drift speed (the difference between the ice velocity and the surface ocean current) should be used, so ocean currents are presumed small compared to drift velocity in our approximation. For the R-Buoy, in order to calculate ocean 
Table 2. Melt rates $\left(\mathrm{m} \mathrm{d}^{-1}\right)$ of the two buoys in different time periods

\begin{tabular}{|c|c|c|c|c|c|c|}
\hline & $\begin{array}{c}30 \text { Dec-13 Jan } \\
\text { Period } 1\end{array}$ & $\begin{array}{l}13 \text { Jan-14 Jan } \\
\text { Period } 2\end{array}$ & $\begin{array}{l}14 \text { Jan-20 Jan } \\
\text { Period } 3\end{array}$ & $\begin{array}{l}20 \text { Jan-26 Jan } \\
\text { Period } 4\end{array}$ & $\begin{array}{l}26 \text { Jan-10 Feb } \\
\text { Period } 5\end{array}$ & Average (heat flux in $\mathrm{W} \mathrm{m}^{-2}$ ) \\
\hline \multirow{4}{*}{$\begin{array}{l}\text { Melt rate } \\
\left(\mathrm{m} \mathrm{d}^{-1}\right) \\
\text { R-Buoy }\end{array}$} & 0.026 & 0.00 & 0.068 & 0.011 & 0.029 & $0.028(79)$ \\
\hline & & & & & & \\
\hline & 10 Jan-1 Feb & & & & 1-7 Feb & \\
\hline & Period 1 & & & & Period 2 & \\
\hline $\begin{array}{l}\text { Melt Rate } \\
\left(\mathrm{m} \mathrm{d}^{-1}\right)\end{array}$ & 0.014 & & & & 0.065 & $0.023(67)$ \\
\hline S-Buoy & & & & & & \\
\hline
\end{tabular}

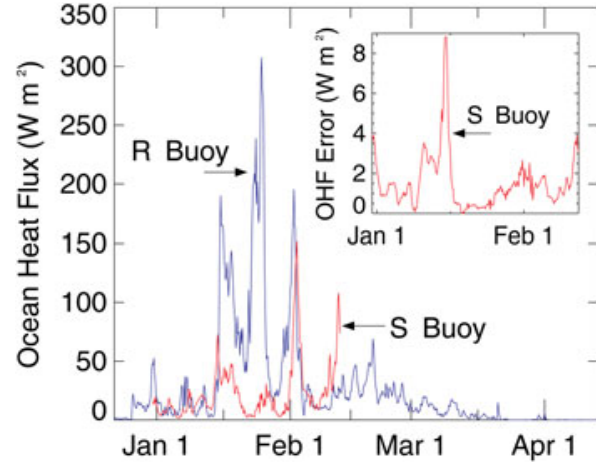

Fig. 8. Ocean heat flux determined with time (31 Dec 2010-13 Feb 2011) from the S-Buoy (red line). The ocean heat flux was determined using the temperature and in situ freezing point determined from the measurements of conductivity, temperature and pressure (depth) made by the CTD. Ocean heat flux determined with time (22 Dec 2010-13 Apr 2011) for the R-Buoy (blue line). The ocean heat flux was determined from the water temperature while the freezing point temperature used was the average value determined using the average salinity derived from the SeaBird conductivity record ( $33.3 \mathrm{psu})$. Ocean heat flux was nearly zero at the beginning (22 Dec-29 Dec 2010) and end (20 Mar-13 Apr 2011) of the records. (Note from Fig. 3 that temperatures within the ice are colder than the freezing points at these times also.) The smaller inset figure shows ocean heat flux error for the S-Buoy with time, determined by differencing (absolute) the ocean heat flux determined from in situ freezing point with the ocean heat flux determined by using the average salinity for the entire record (31 Dec 2010-13 Feb 2011) to determine a single average freezing point temperature. The average error is $\sim 2 \mathrm{~W} \mathrm{~m}^{-2}$.

heat flux from under-ice water temperatures and drift speeds, we used the average salinity derived from the salinity measurements on the S-Buoy to calculate the freezing point temperature. In order to determine how this affects the ocean heat flux calculation, we computed the difference between the heat flux determined using the S-Buoy instantaneous freezing point temperature compared to the heat flux determined using the S-Buoy average freezing point temperature. This difference is shown in Figure 8 (inset) as the absolute difference for each point. With few exceptions, the difference is $<2 \mathrm{~W} \mathrm{~m}^{-2}$, that is an average absolute error of only $\pm 2 \mathrm{~W} \mathrm{~m}^{-2}$. These errors in heat flux due to the average freezing point assumption are therefore small compared to the magnitude of the temperature elevation and introduce tolerable error (discussed further in the next section) for warmer water temperatures. When the temperature is close to the freezing point, even though the error as a percentage of the heat flux may be large, the actual heat flux is also small and only results in small ice thickness change errors.

In order to compare the ocean heat flux from the ice thickness changes with that from the ocean measurements, the average of the ocean heat flux of the S-Buoy in Figure 8 (red line) from January 10 to February 1 is $19 \mathrm{~W} \mathrm{~m}^{-2}$, compared to an estimated $40 \mathrm{~W} \mathrm{~m}^{-2}$ from ice thickness regression $\left(1.4 \mathrm{~cm} \mathrm{~d}^{-1}\right)$. From 1 February until 7 February, the average S-Buoy ocean heat flux is
$82 \mathrm{~W} \mathrm{~m}^{-2}$, compared to an estimated $\sim 200 \mathrm{~W} \mathrm{~m}^{-2}$ from ice thickness change $\left(6.5 \mathrm{~cm} \mathrm{~d}^{-1}\right)$.

In Figure 8, the estimate for the R-Buoy of ocean heat flux (shown as the blue line) is similarly made. Comparing the R-Buoy ocean heat flux with ice thickness changes, the average ocean heat flux computed from 1 January to 10 February is 55 $\mathrm{W} \mathrm{m} \mathrm{m}^{-2}$, compared to an estimated $79 \mathrm{~W} \mathrm{~m}^{-2}$ ocean heat flux from measured ice thickness rate change of $\sim 2.7 \mathrm{~cm} \mathrm{~d}^{-1}$.

\section{Discussion}

Differences in heat flux derived from ocean properties and ice thickness determinations

The comparison between the estimated ocean heat flux from ice thickness changes gave larger values for the heat flux compared to ocean heat flux computed from ocean temperature and properties. Expressed in melt rates, the ocean heat flux during January from S-Buoy ocean properties would give a melt rate of only $0.6 \mathrm{~cm} \mathrm{~d}^{-1}$ compared to measured melt rate of $1.4 \mathrm{~cm} \mathrm{~d}^{-1}$ from ice thickness changes. From the R-Buoy during January, an ocean heat flux-derived melt rate would be $\sim 2 \mathrm{~cm} \mathrm{~d}^{-1}$ compared to the melt rate from measured ice thickness change of 2.7-2.8 $\mathrm{cm} \mathrm{d}^{-1}$. One of the reasons for this discrepancy may be the latent heat value used for the ice (Eqn (3); Ono, 1968). If, instead, the sea ice has undergone a significant amount of interior melt deterioration, it may structurally have $\mathrm{cm}$-sized brine channels as observed previously in cores taken at the end of summer in the Weddell Sea pack ice (Weeks and Ackley, 1986). As this deteriorated ice melts from below, this ice cover could have a smaller apparent latent heat per unit volume and may instead respond as shown here with a higher melt rate than a more intact ice cover would respond to the same ocean heat flux. The error from freezing point temperature changes is apparently small as estimated in Figure 8 and discussed earlier. The data point variations in the ice thickness regression plots (Fig. 7) show that there can be significant (and probably spurious short-term variation) uncertainty in the sonar-determined ice bottom profile that may also make it difficult to determine the ice thickness changes over short times. This variation is probably due to the variable reflection properties of a rough ice bottom as discussed earlier.

The ocean heat flux determination from ocean properties relies on a literature-derived value for the coefficient (Morison, 1995; McPhee and others, 1999), and uses a constant scaling between ice drift speed and friction velocity. This may be a poor approximation as this relationship depends on ice bottom conditions (rough or smooth) which cannot be independently determined here. Ice drift speed, water salinity profile (stability) and other factors may also change the heat transfer coefficient (e.g. Morison, 1995; McPhee and others, 1999). However, Ackley and others (2015), for similar comparisons of ice thickness changes and bulk parameterization of ocean heat flux from Antarctic IMB buoy measurements in spring and fall, found instead good 
agreement between the two ocean heat flux determinations using the same heat transfer coefficients as here. With the absence of direct measurements, particularly of drag coefficients, whether changes in the coefficients or the porosity changes in the ice account for the differences is indeterminate at this point. It may also instead be a combination of both these factors.

\section{Summer surface flooding processes in the Amundsen Sea ice pack}

Mechanisms previously discussed for surface flooding, particularly for the Amundsen Sea region, focused their attention on winter increases in snow depth causing the ice surface to be pushed below sea level and causing sea water to intrude (Maksym and Jeffries, 2000; Perovich and others, 2004). We investigated instead an increase in surface flooding depth in summer due to ice bottom melting. The mechanism in summer for increasing the depth of flooding was caused by the substantial decrease in ice thickness which progressively raised the sea level into the snow cover to maintain isostatic balance in the floe. The process to increase the depth of the flooded layer was vertical in nature and did not require additional snowfall. At the end of the summer period for both the R-Buoy and S-Buoy sites, a total of $\sim 0.3-0.35 \mathrm{~m}$ of flooded snow was found for each site.

\section{Warm surface water as the source of high ocean heat fluxes in the summer pack ice zone}

Water temperatures for the R-Buoy (Fig. 3d, bottom), an average of $0.47^{\circ} \mathrm{C}$ above the freezing point temperature (from 1 January to 10 February), showed high values starting near the end of December and continuing through early February, when cooling back to the freezing point commenced from about mid-February and continued until April. Water temperatures were generally cooler for the S-Buoy (Fig. 2d) (average of $0.21^{\circ}$ $\mathrm{C}$ above the freezing point from 1 January until 9 February) and, particularly, were cooler during the mid-January period of peak temperatures for both buoys. In spring and fall, however, Ackley and others (2015) found near surface water temperature freezing point elevation was $<0.10^{\circ} \mathrm{C}$, or two to five times lower than these summer values in the Amundsen Sea. The difference in water temperatures (Figs $2 \mathrm{~d}$ and $3 \mathrm{~d}$ ), higher for the R-Buoy, suggests the water temperatures for the two buoys, despite being in a similar area oceanographically, were controlled by ice concentration differences that the two buoys encountered. Figure 1 shows the ice concentration map on 11 January, derived from passive microwave satellite data (Cavalieri and others, 1996), and the buoy tracks of the two buoys. We analyzed the ice concentration variations by taking the daily ice concentration at each buoy position. This analysis showed on average $20 \%$ less ice concentration at the R-Buoy site than the S-Buoy site from 1 January through mid-January. The R-Buoy was closer to the coast during mid-January where offshore winds generally kept ice away (a coastal polynya), resulting in lower ice concentration (Fig. 1). Because of its lower albedo, the higher amount of open water absorbed more solar radiation prior to and during the buoy drift through the region leading to the warmer water temperatures on the R-Buoy track (Fig. 5). The S-Buoy drift was more offshore over waters covered with ice of higher ice concentration (Fig. 1) and resulted in lower temperatures and lower ocean heat flux along the S-Buoy's path during January.

The low snow accumulation $(<10 \mathrm{~cm})$ observed during January and February (Figs $2 \mathrm{c}$ and $3 \mathrm{c}$ ) showed that other observations (e.g. Perovich and others, 2004) showing surface flooding controlled by precipitation in other seasons (spring) was not seen in summer here. For the R-Buoy site, $1.1 \mathrm{~m}$ of bottom melt caused by high ocean heat flux also created $\sim 0.3-0.35 \mathrm{~m}$ of flooded snow. In March-April, the flooded layer on the R-Buoy site was lowered in temperature and therefore froze as snow ice (Fig. 3c). The total thickness at this time was $\sim 1.1-1.2 \mathrm{~m}$ of sea ice with $\sim 25 \%(0.3-$ $0.35 \mathrm{~m}$ ) added on as this new snow ice. Measurements of cores taken further west in the outflow regions of the eastern Amundsen Sea have found, on average, larger percentages of snow ice $(\sim 30 \%)$ than found in other areas of Antarctica (Jeffries and others, 1998; Ackley and others, 2003). These larger percentages of snow ice are therefore commensurate with summer bottom melting causing increased flooding, followed by fall freeze-up, as well as possibly greater winter snowfall in the Amundsen Sea than elsewhere (e.g. Maksym and Markus, 2008). For the offshore S-Buoy site, ocean heat flux values offshore, while lower, still averaged $18.4 \mathrm{~W} \mathrm{~m}^{-2}$ during January and were similar to SHEBA mass-balance sites in the Arctic where values increased to more than $15 \mathrm{~W} \mathrm{~m}^{-2}$ during summer (Perovich and Elder, 2002). The Arctic warming was also attributed to solar heating of the waters in lower ice concentrations and caused high levels of bottom sea-ice melt there.

\section{Conclusions}

The variation in water temperature between the two buoy tracks and resulting differences in ocean heat flux-induced bottom melting illustrate the strong control that ice concentration variations have on the process of surface flooding caused by bottom melting in summer. While these measurements are presently only from the Amundsen Sea pack ice, there is implied dependence of water temperature and summer ocean heat flux on ice concentration, rather than regional water mass properties. This behavior suggests that remote sensing and an ice dynamics model, through ice concentration and water temperature predictions, can provide some estimates of bottom melting and surface flooding in summer ice conditions on a wider basis in both the Antarctic and Arctic pack ice zones for climate and biogeochemistry models. Still, additional year-round deployments of IMB buoys, together with high-resolution modeling and remote-sensing analyses over the buoy sites, are needed to better quantify these relationships and for validation of their derivation from these modeling or remote-sensing analyses.

Acknowledgement. This work was supported by the National Science Foundation grant to UTSA, ANT-0839053-Sea Ice System in Antarctic Summer (S.F. Ackley, H. Xie and B. Weissling), and to WHOI, ANT-1341513 (T. Maksym), and by the NASA Center for Advanced Measurements in Extreme Environments or NASA-CAMEE at UTSA, NASA \#80NSSC19M0194 (S.F. Ackley, H. Xie, B.Weissling).

Author contribution. D.P. constructed and calibrated the IMBs and reduced the buoy data. B.W. installed the buoys in the Amundsen Sea pack ice. S.A. and H.X. conducted the analyses with assistance from T.M., D.P. and B.W. S.A wrote the first draft of the paper and all authors contributed to rewriting, figure production and editing.

\section{References}

Ackley S (2013) The sea ice system in Antarctic summer, Oden Southern Ocean Expedition (OSO 2010-11), U.S. Antarctic Program (USAP) Data Center. doi: 10.15784/600106.

Ackley SF, Xie H and Tichenor EA (2015) Ocean heat flux under Antarctic sea ice in the Bellingshausen and Amundsen Seas: two case studies. Annals of Glaciology 56(69), 2015. doi: 10.3189/2015AoG69A890

Ackley SF and 14 others (2003) A top-down, multidisciplinary study of the structure and function of the pack-ice ecosystem in the eastern Ross Sea Antarctica. Polar Record 39, 219-230. doi: 10.1017/S0032247403003115

Adolphs U (1998) Ice thickness variability, isostatic balance and potential for snow ice formation on ice floes in the south polar Pacific Ocean. Journal of 
Geophysical Research 103, 24675-24691. doi: https://doi.org/10.1029/ 98JC02414

Cavalieri DJ, Parkinson CL, Gloersen P and Zwally H (1996, updated yearly) Sea Ice Concentrations from Nimbus-7 SMMR and DMSP SSM/I-SSMIS Passive Microwave Data. [south-pole daily sea ice concentration]. Boulder, Colorado, USA: NASA National Snow and Ice Data Center Distributed Active Archive Center.

Eicken H, Lange M, Hubberten H-W and Wadhams P (1994) Characteristics and distribution patterns of snow and meteoric ice in the Weddell Sea and their contribution to the mass balance of sea ice. Annals of Geophysics 12, 80-93. doi: $10.1007 / \mathrm{s} 00585-994-0080-\mathrm{x}$

Fofonoff NP (1985) Physical properties of seawater: a new salinity scale and equation of state for seawater. Journal of Geophysical Research 90(C2), 3332-3342. doi: 10.1029/JC090iC02p03332

Fritsen CH, Ackley SF, Kremer JN and Sullivan CW (1998) Flood-freeze cycles and microalgal dynamics in Antarctic pack ice. In Lizotte $\mathrm{M}$ and Arrigo KR (ed.), Antarctic Sea Ice: Biological Processes, Interactions and Variability, Antarctic Research Series, vol.73. Washington, DC: AGU, pp. $1-22$.

Fujino K, Lewis EL and Perkin RG (1974) The freezing point of seawater at pressures up to 100 bars. Journal of Geophysical Research 79(12), 17921797. doi: https://doi.org/10.1029/JC079i012p01792.

Golden KM, Ackley SF and Lytle VI (1998) The percolation phase transition in sea ice. Science (New York, NY) 282, 2238-2241. doi: 10.1126/science. 282.5397.2238

Haas C, Thomas DN and Bareiss J (2001) Surface properties and processes of perennial Antarctic sea ice in summer. Journal of Glaciology 47(159), 613-625.

Jeffries MO, Li S, Jana RA, Krouse HR and Hurst-Cushing B (1998) Late winter first-year ice floe thickness variability, seawater flooding and snow ice formation in the Amundsen and Ross Seas. In Jeffries MO (ed.), Antarctic Sea Ice: Physical Processes, Interactions and Variability. Antarctic Research Series, vol. 74, Washington, DC: AGU, pp. 69-87.

Jeffries MO, Krouse HR, Hurst-Cushing B and Maksym T (2001) Snow-ice accretion and snow-cover depletion on Antarctic first-year sea-ice floes. Annals of Glaciology 33, 51-60. http://dx.doi.org/10.3189/172756401781818266

Josberger EG (1987) Bottom ablation and heat transfer coefficients from the 1983 marginal ice zone experiments. Journal of Geophysical Research 92 (C7), 7012-7016. https://doi.org/10.1029/JC092iC07p07012

Lewis MJ and 6 others (2011) Sea ice and snow cover characteristics during the winter-spring transition in the Bellingshausen Sea: an overview of SIMBA 2007, Deep Sea Research II. doi:10.1016/j.dsr2.2010.10.027

Lytle VI and Ackley SF (1996) Heat flux through sea ice in the western Weddell Sea: convective and conductive transfer processes. Journal of Geophysical Research 101, 8853-8868. doi: https://doi.org/10.1029/95jc03675

Lytle VI and Ackley SF (2001) Snow-ice growth: a fresh-water flux inhibiting deep convection in the Weddell Sea, Antarctica. Annals of Glaciology 33, 45-50. http://dx.doi.org/10.3189/172756401781818752

Maksym T and Jeffries MO (2000) A one-dimensional percolation model of flooding and snow-ice formation on Antarctic sea ice. Journal of Geophysical Research 105, 26313-26331. https://doi.org/10.1029/2000JC900130
Maksym T and Markus T (2008) Antarctic sea ice thickness and snow-to-ice conversion from atmospheric reanalysis and passive microwave snow depth. Journal of Geophysical Research 113(C2), C02S12. (10.1029/2006JC004085.)

Maksym T, Stammerjohn SE, Ackley S and Massom R (2012) Antarctic sea ice - a polar opposite? Oceanography 25(3), 140-151. http://dx.doi.org/10. 5670/oceanog.2012.88

Maykut GA (1986) The surface heat and mass balance, Chap.5. In Untersteiner N ed. The Geophysics of Sea Ice, NATO, 451 Set. 3, vol. 146. New York: Plenum Press, 395-464.

McPhee M (1995) Ocean flux measurements during the ANZFLUX experiment. Antarctic Journal of the United States 30, 122-124.

McPhee M and 8 others (1996) The Antarctic zone flux experiment. Bulletin of the American Meteorological Society 77(6), 1221-1232. doi: 10.1175/ 1520-0477(1996)029<1166:OHFITC >2.0.CO;2

McPhee MG (2008) Physics of early summer ice/ocean exchanges in the western Weddell Sea during ISPOL. Deep-Sea Research II 55(2008), 1075-1097. doi: $10.1016 /$ j.dsr2.2007.12.022

McPhee MG, Kottmeier C and Morison JH (1999) Ocean heat flux in the central Weddell Sea during winter. Journal of Physical Oceanography 29, 1166-1179. https://doi.org/10.1175/1520-0485(1999)029\%3C1166:OHFITC \%3E2.0.CO;2

Morison JH (1995) Autonomous vehicle and hydrographic buoy measurements during ANZFLUX. Antarctic Zone Flux Experiment (ANFLUX). Antarctic Journal of the United States 30, 131-133.

Morison JH, McPhee MG and Maykut GA (1987) Boundary layer, upper ocean and ice observations in the Greenland Sea marginal ice zone. Journal of Geophysical Research 92(C7), 6987-7011.

Omstedt A and Wettlaufer JS (1992) Ice growth and oceanic heat flux: models and measurements. Journal of Geophysical Research 97(C6), 9383-9390.

Ono N (1968) Thermal properties of sea ice, IV. Thermal constants of sea ice. Low Temperature Science, A 26, 329-349.

Perovich DK and Elder B (2002) Estimates of ocean heat flux at SHEBA Geophysical Research Letters 29(9), 58-1-58-4. doi: doi:10.1029/ $2001 G L 014171$.

Perovich DK and 7 others (2004) Sea-ice properties in Marguerite Bay, Antarctica. Deep-Sea Research Part II 51, 2023-2039.

Shirasawa K and Lepparanta M (2009) Measurements and modeling of the ice-ocean interaction. In Eicken H, Gradinger R, Salganek M, Shirasawa K, Perovich D and Lepparanta M (eds), Field Techniques for Sea Ice Research. Fairbanks: Univ of Alaska Press, pp. 231-258.

Sirevaag A, McPhee MG, Morison JH, Shaw WJ and Stanton TP (2010) Wintertime mixed layer measurements at Maud Rise, Weddell Sea. Journal of Geophysical Research 115, C02009. doi: doi:10.1029/2008JC005141

Weeks WF and Ackley SF (1986) The growth, structure and properties of sea ice, Chap.1. In Untersteiner N (ed.), The Geophysics of Sea Ice, NATO, 451 Set. 3, vol. 146. New York: Plenum Press, pp. 9-146.

Worby AP, Massom RA, Allison I, Lytle VI and Heil P (1998) East Antarctic sea ice: a review of its structure, properties and drift. Antarctic sea ice: physical processes, interactions and variability. Antarctic Research Series 74, 41-67. 